Research Paper

International Journal of Biological Sciences

ISSN 1449-2288 www.biolsci.org 2008 4(6):362-367

(C) Ivyspring International Publisher. All rights reserved

\title{
Association of Insertion/Deletion Polymorphism of Alpha-Adrenoceptor Gene in Essential Hypertension with or without Type 2 Diabetes Mellitus in Malaysian Subjects
}

\author{
R. Vasudevan ${ }^{1}$, Patimah Ismail ${ }^{1}{ }^{凶}$, Johnson Stanslas ${ }^{1}$, Norashikin Shamsudin², Aisyah binti Ali1 \\ 1. Molecular Biology Lab, Department of Biomedical Science, Universiti Putra Malaysia, Serdang 43400, Malaysia \\ 2. Department of Medicine, Faculty of Medicine and Health Sciences, Serdang 43400, Malaysia
}

$\triangle$ Correspondence to: Prof. Dr. Patimah Ismail, Department of Biomedical Science, Faculty of Medicine and Health Sciences, Universiti Putra Malaysia, Serdang 43400, Selangor DE, Malaysia. Tel: 603-89472314; Fax: 603- 89436178; e-mail: patimah@medic.upm.edu.my

Received: 2008.06.10; Accepted: 2008.09.29; Published: 2008.10.05

An insertion/deletion (I/D) polymorphism of Alpha2B-Adrenoceptor (ADRA2B) gene located on chromosome 2 has been studied extensively in related to cardiovascular diseases. The main aim of the present study was to examine the potential association of D allele frequency of I/D polymorphism of ADRA2B gene in Malaysian essential hypertensive subjects with or without type 2 diabetes mellitus (T2DM). This study includes 70 hypertensive subjects without T2DM, 65 hypertensive subjects with T2DM and 75 healthy volunteers as control subjects. Genotyping of I/D polymorphism was performed by conventional PCR method. There was significant difference found in age, body mass index, systolic/diastolic blood pressure and high density lipoprotein cholesterol level between the case and control subjects. DD genotypic frequency of I/D polymorphism was significantly higher in hypertensive subjects $(42.84 \%$ vs. $29.33 \% ; P=0.029)$ and in hypertensive with T2DM subjects $(46.15 \%$ vs. $29.33 \% ; P=0.046)$ than control group. D allele frequency was higher in hypertensive group $(67.41 \%)$ than control subjects $(52.67 \%)$. However, no significant difference was found between the three genotypes of I/D polymorphism of ADRA2B gene and the clinical characteristics of the subjects. The result obtained in this study show D allele of ADRA2B gene was associated with essential hypertension with or without T2DM in Malaysian subjects.

Key words: Alpha2B-Adrenoceptor, Essential hypertension, Type 2 Diabetes Mellitus, Insertion/Deletion polymorphism

\section{Introduction}

Essential hypertension (EHT) is a major public health burden worldwide and it is a growing concern in Malaysia [1]. According to the National Health and Morbidity Survey in Malaysia (1996), a prevalence of $33 \%$ or an estimated of 2.6 million Malaysian adults aged $\geq 30$ years had hypertension [2]. In order to identify the candidate genes in predisposition to EHT, several studies had been carried out extensively in various populations and indicate the important contribution of genetic variants of many gene loci to EHT $[3,4]$. In that way, recent studies suggested that, a common variant (12Glu9) of the human $\mathrm{a}_{2 \mathrm{~B}}$-adrenergic gene (ADRA2B) encodes a receptor protein leading to the insertion/deletion (I/D) of three consecutive glutamate residues at amino acid positions 301 to 303 has been associated with EHT [5, 6], acute coronary events [7]. In-vitro studies showed, I/D polymorphism of ADRA2B gene to affect an impaired agonist-induced desensitization of the receptor [8]. D variant of I/D polymorphism of ADRA2B gene influence the sympathetic nervous system activity and meant of to develop EHT. It was also associated with impaired first phase insulin secretion and may predict the development of T2DM in subjects with impaired glucose tolerance [9].

In a population-based, prospective study on 912 middle-aged men, the DD genotype was associated with an increased incidence of acute myocardial infarction [10]. In addition, a cross-sectional clinical study in the Brazilian population suggested that 12Glu9 deletion polymorphism of ADRA2B gene might result in reduced autonomic responsiveness by altering cardiac sympathetic and vagal function during sustained handgrip exercise in normotensive obese women [11]. Another study indicated D allele may be implicated in impaired glucose metabolism leading to earlier manifestation of diabetes in predisposed subjects in Greek population [12]. 
In Chinese men [13], the I allele of the ADRA2B gene was strongly associated with higher blood pressure while D allele was not associated in a cohort of middle-aged men from Eastern Finnish population [14], however subjects with D allele had an increased risk of developing T2DM in Finnish population [9]. In a controlled 10 years follow-up study in 126 non-diabetic control subjects and 84 newly diagnosed, middle-aged T2DM patients from Eastern Finland, predicted a greater increase in body weight among non-diabetic subjects but not in type 2 diabetic subjects [15]. In addition, I/D polymorphism of ADRA2B gene was not associated with late complications in type 1 diabetic patients [16] and EHT $[7,17]$. These controversial results initiated us to determine the association of I/D polymorphism of ADRA2B gene in Malaysian essential hypertensive subjects with or without T2DM.

\section{Materials and Methods}

\section{Ethics}

The study protocol was approved by the Ethical Committee of the Faculty of Medical and Health Science (UPM/FPSK/PADS/T-TAD/T7-MJKEtikaPPer /F01); Universiti Putra Malaysia (UPM). Written informed consent was obtained from all the respondents.

\section{Study Subjects}

A total of 70 hypertensive subjects without T2DM and 65 hypertensive subjects with T2DM were recruited in this study. All the patients were consecutively attended at UPM Physician clinic and the medical wards; Hospital Kuala Lumpur from April 2006-April 2007. The subjects were selected under the inclusion and exclusion criteria. Essential hypertensive subjects were defined as those with systolic blood pressure (SBP) of $\geq 140 \mathrm{~mm} \mathrm{Hg}$ and/or diastolic blood pressure (DBP) of $\geq 90 \mathrm{~mm} \mathrm{Hg}$, or those currently receiving anti-hypertensive therapy. After the subjects have been seated and rested for 5 minutes, the blood pressure was measured using an automated blood pressure meter (Omron, Japan) on the right arm of the subjects. T2DM was defined under the criteria of American Diabetes Association as fasting plasma glucose was $>7.0 \mathrm{mmol} / \mathrm{L}$ and the levels were obtained from the medical records of the subjects. Seventy five unrelated healthy individuals were recruited randomly with a negative history of hypertension and diabetes from UPM staff members and the volunteers. They were categorized with resting SBP $<140$ and DBP $<90 \mathrm{mmHg}$ on at least two separate occasions and none of them were receiving any medications at the time of participation. The subjects were divided as group 1 (EHT without T2DM), group 2 (EHT with T2DM) and the control subjects as group 3. The sub- jects were also categorized under the three major ethnic groups as Malays, Chinese and Indians. Questionnaires in both Malay and English language were prepared to asses the socio-demographic factors, history and the duration of hypertension and T2DM.

\section{Sample Collection and Biochemical Analysis}

Four-five milliliters of peripheral blood samples were collected and transferred into an EDTA tube (Becton Dickinson, Franklin Lakes, NJ) by a qualified phlebotomist. Plasma was separated from the blood by centrifuge at $4000 \mathrm{rpm}$ and stored at $-20^{\circ} \mathrm{C}$ until further analysis. Individual weight and height were obtained to calculate body mass index (BMI) using the formula, weight $(\mathrm{kg}) /$ [height $\left(\mathrm{m}^{2}\right)$ ]. To determine the levels of triglycerides (TG), high density lipoprotein cholesterol (HDL-C) and total cholesterol (TC), plasma samples was analyzed using Hitachi-912 Autoanalyser (Mannheim, Germany) with kits supplied by Roche Diagnostics (Mannheim, Germany). Low density lipoprotein cholesterol (LDL-C) was calculated using Friedewald formula [18].

\section{Genotyping Methods}

Genomic DNA was extracted from peripheral blood using Genomic DNA isolation kit (BioBasic.Inc, Toronto, Canada). The concentration and the purity of extracted DNA were quantified by spectrophotometry, using biophotometer UVette (Eppendorf, Hamburg, Germany). To determine the I/D polymorphism of ADRA2B gene, polymerase chain reaction (PCR) method [7] was used with forward primer: 5'-AGG-GTG-TTT-GTG-GGG-CAT-CT-3' and reverse primer: 5'-CAA-GCT-GAG-GCC-GGAGACACT-3' (synthesized by Research Biolabs, Selangor, Malaysia). A total volume of $25 \mu \mathrm{L}$ reaction mixture contain 20 pmol of each primer, $0.4 \mathrm{mmol} / \mathrm{L}$ of dNTP, $2 \mathrm{mmol} / \mathrm{L}$ of $\mathrm{MgCl}_{2}, 1 x$ Taq buffer, 1 unit of NEB Taq DNA polymerase (New England Biolabs, Beverly, MA, USA) and the template DNA was used for amplification of I/D polymorphism of ADRA2B gene. The PCR cycling conditions were carried out on iCycler (BioRad Laboratories, Hercules, California, USA). The initial denaturation was set up for 10 minutes at $95^{\circ} \mathrm{C}$ followed by 35 cycles of denaturation for 1 minute at $94^{\circ} \mathrm{C}$, annealing for 2 minutes at $58^{\circ} \mathrm{C}$, extension for 1 minute at $72^{\circ} \mathrm{C}$ and the final extension was at $72^{\circ} \mathrm{C}$ for 2 minutes. The size of the PCR products was clearly resolved on 3\% Metaphor agarose gel (Cambrex, East Rutherford, NJ, USA) which has been performed in Origins electrophoresis (Elchrom Scientific AG, Cham, Switzerland) and then the gel was stained in ethidium bromide. The DNA fragments were visualized under UV light using Alpha Imager (Alpha Innotech, San Leandro, CA). Identical results were obtained when geno- 
typing was performed on two separate occasions for $10 \%$ of the samples.

\section{Statistical Analysis}

All the statistical analysis was carried out by using SPSS (Chicago, IL, USA) software version 14.0 for Microsoft Windows ${ }^{\circledR}$. Clinical characteristics of all the subjects were expressed as mean \pm SD. Continuous variables were compared between the groups by using two-tailed student's $t$ test. Allelic frequencies were calculated by gene-counting method and the genotypic and allelic distribution of I/D polymorphism of ADRA2B gene were analyzed using chi-square test. The effect of I/D genotypes of ADRA2B was analyzed using general linear model ANOVA for clinical charateristics. A level of $P<0.05$ was considered statistically significant.

\section{Results}

A total of 230 subjects were recruited and 210 subjects were included in this study, since 20 subjects were excluded due to inconsistent results of genotypes and the extreme clinical characteristic values. This study consisted of 70 hypertensive subjects (group 1) (mean age $57.00 \pm 11.02$ years), 65 hypertensive subjects with T2DM (group 2) (mean age 57.62 \pm 9.76 years) and 75 unrelated healthy controls as group 3 (mean age $45.37 \pm 10.72$ years). Table 1 shows the baseline characteristics of all the study subjects. The majority of the subjects involved in this study were males [130 $(61.90 \%)]$ as compared to females [80 (38.10\%)]. None of the healthy subjects had a family history of hypertension but among group 1; 55.71\% and $66.15 \%$ of group 2 subjects had a family history of either hypertension or diabetes. There were no significant differences observed in all of the variables analyzed between the groups except for age, BMI, SBP, DBP and HDL-Cholesterol $(\mathrm{p}<0.05)$.

Table 1. Baseline charecterisitics of all the subjects

\begin{tabular}{llll}
\hline Parameters & Group 1 & Group 2 & Group 3 \\
\hline Gender (M/F) & $51 / 19^{*}$ & $40 / 25$ & $39 / 36$ \\
\hline $\begin{array}{l}\text { Age (Years) } \\
\text { Smoking }\end{array}$ & $57.00 \pm 11.02^{*}$ & $57.62 \pm 9.76^{*}$ & $45.37 \pm 10.72$ \\
\hline $\begin{array}{l}\text { Duration of EHT (Years) } \\
\text { Duration of T2DM } \\
\text { (Years) }\end{array}$ & $26 / 44$ & $26 / 39$ & $20 / 55$ \\
\hline $\begin{array}{l}\text { Family History } \\
\text { (Yes/No) }\end{array}$ & $39 / 31$ & $43 / 22$ & - \\
BMI (kg/m2) & $25.63 \pm 4.15^{*}$ & $26.71 \pm 3.60^{*}$ & $23.96 \pm 4.15$ \\
\hline SBP $(\mathrm{mm} \mathrm{Hg})$ & $160.21 \pm 19.26^{*} 160.26 \pm 19.01^{*} 125.98 \pm 8.81$ \\
DBP (mm Hg) & $97.77 \pm 10.77^{*}$ & $93.82 \pm 4.47^{*}$ & $77.83 \pm 7.09$ \\
\hline TC (mmol/L) & $4.88 \pm 1.36$ & $5.16 \pm 1.62$ & $5.12 \pm 1.39$ \\
\hline HDL-C (mmol/L) & $0.88 \pm 0.41^{*}$ & $0.78 \pm 0.31^{*}$ & $1.68 \pm 1.10$ \\
\hline LDL-C (mmol/L) & $3.50 \pm 1.35$ & $3.87 \pm 1.55$ & $3.38 \pm 1.21$ \\
\hline TG (mmol/L) & $2.04 \pm 1.20$ & $2.01 \pm 1.02$ & $1.12 \pm 0.40$ \\
\hline * P value < 0.05 vs. group 3 obtained through two-tailed student's t \\
test.
\end{tabular}

Genotypes of I/D polymorphism of ADRA2B gene was determined by separating the PCR amplified DNA fragments on gel electrophoresis (figure 1). The identification of $112 \mathrm{bp}$ fragments for the long allele (I) and 103bp for short allele (D) was carried out. The genotypic and allelic distribution of I/D polymorphism of ADRA2B gene among the groups are shown in the Table 2. The results from this study show a high prevalence of DD genotype in the total hypertensive subjects $(44.51 \%)$ when compared to control subjects $(29.33 \%)$. The frequency of the D allele in group 1 was $67.14 \%$ and $67.69 \%$ in group 2 when compared to group 3 subjects $(52.67 \%)$. Significant difference was observed in genotypic and allelic frequencies among the case and control subjects $(\mathrm{p}<0.05)$.

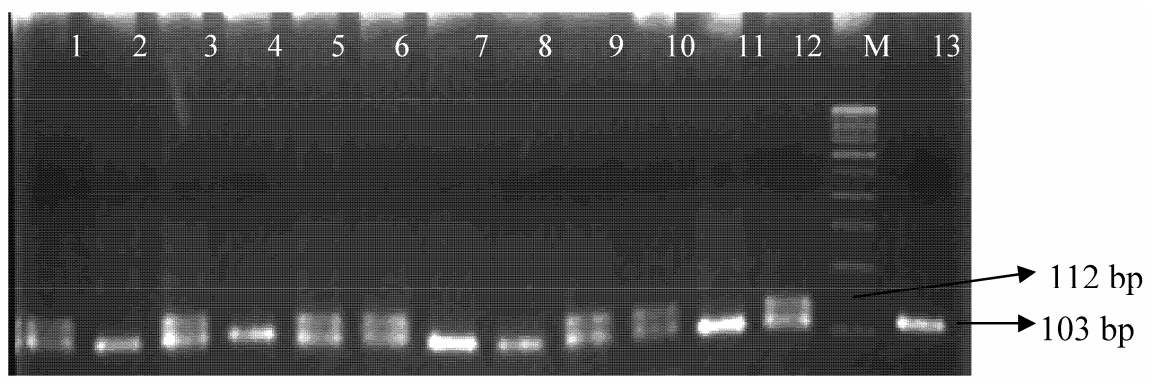

Figure 1: PCR products in 3\% Metaphor agarose gel electrophoresis. Lanes 1, 3, 5, 6, 9, 10, 12 show heterozygous ID genotypes, lanes 2, 7, 8, 11, 13 show homozygous DD genotypes and lane 4 shows homozygous II genotype. M represents a 100 bp DNA ladder (Fermentas). 
Table 2: Genotypic and allelic distributions of I/D polymorphism of ADRA2B gene among the groups.

\begin{tabular}{|l|l|l|l|}
\hline Genotypes & $\begin{array}{l}\text { Group 1 } \\
\mathbf{( 7 0 )}\end{array}$ & $\begin{array}{l}\text { Group 2 } \\
\mathbf{( 6 5 )}\end{array}$ & $\begin{array}{l}\text { Group 3 } \\
\mathbf{( 7 5 )}\end{array}$ \\
\hline $\mathbf{n ~ ( \% )}$ & $\mathbf{n}(\mathbf{\%})$ & $\mathbf{n}(\mathbf{\%})$ \\
\hline II & $6(8.57)$ & $7(10.77)$ & $18(24.00)$ \\
\hline ID & $34(48.57)$ & $28(43.08)$ & $35(46.67)$ \\
\hline DD & $30(42.86)$ & $30(46.15)$ & $22(29.33)$ \\
\hline Significance & $\mathbf{0 . 0 2 9 *}$ & $\mathbf{0 . 0 4 6 *}$ & - \\
\hline Alleles I & $46(32.86)$ & $42(32.31)$ & $71(47.33)$ \\
\hline D & $94(67.14)$ & $88(67.69)$ & $79(52.67)$ \\
\hline Significance & $\mathbf{0 . 0 1 2 *}$ & $\mathbf{0 . 0 1 1 ^ { * }}$ & - \\
\hline Odds Ratio & 0.545 & 0.531 & - \\
\hline $95 \%$ CI & $(0.388-0.837)$ & $(0.326-0.595)$ & \\
\hline
\end{tabular}

* $P$ value $<0.05$ vs. group 3 , obtained through Chi-square test

The genotypic and allelic distributions of I/D polymorphism of ADRA2B gene among male and female subjects are shown in Table 3 . There was no sig- nificant difference in either hypertensive group or in the control group, but in hypertensive subjects with T2DM there was statistically significant differences observed between the gender for genotypes $(P=0.032)$ and alleles $(P=0.012)$ for $\mathrm{I} / \mathrm{D}$ polymorphism of ADRA2B gene.

In addition, the data was stratified to analyze I/D polymorphism of ADRA2B gene with three ethnic groups of Malaysia. There was no significant difference observed between Malays, Chinese and Indians (data not shown). According to the three genotypes of I/D polymorphism of ADRA2B gene, the data was stratified for the clinical characteristics of the subjects and compared using univariate analysis (Table 4). We found no significant differences for the clinical characteristics of the subjects with II, ID and DD genotypes of I/D polymorphism of ADRA2B gene.

Table 3: Genotypic and allelic distributions of I/D polymorphism of ADRA2B gene among male and female subjects.

\begin{tabular}{|c|c|c|c|c|c|c|c|c|c|}
\hline & \multirow[t]{3}{*}{ Gender } & \multicolumn{3}{|c|}{ Genotypes } & \multirow{3}{*}{$\begin{array}{l}P \\
\text { value }\end{array}$} & \multicolumn{2}{|l|}{ Alleles } & \multirow[t]{3}{*}{$P$ value } & \multirow{3}{*}{$\begin{array}{l}\text { OR } \\
95 \% \text { CI }\end{array}$} \\
\hline & & II & ID & DD & & I & D & & \\
\hline & & n (\%) & n (\%) & n (\%) & & n ( $\%)$ & n (\%) & & \\
\hline \multirow[t]{2}{*}{ Group 1} & Male (51) & $\begin{array}{l}3 \\
(5.88)\end{array}$ & $\begin{array}{l}27 \\
(52.94)\end{array}$ & $\begin{array}{l}21 \\
(41.18)\end{array}$ & & $\begin{array}{l}33 \\
(32.35)\end{array}$ & $\begin{array}{l}69 \\
(67.65)\end{array}$ & \multirow[t]{2}{*}{0.842} & \multirow{2}{*}{$\begin{array}{l}0.920 \\
(0.418-2.023\end{array}$} \\
\hline & Female (19) & $\begin{array}{l}3 \\
(15.79)\end{array}$ & 7 & $\begin{array}{l}9 \\
(47.37)\end{array}$ & 0.294 & $\begin{array}{l}13 \\
(34.21)\end{array}$ & $\begin{array}{l}25 \\
(65.79)\end{array}$ & & \\
\hline \multirow[t]{2}{*}{ Group 2} & Male (40) & $\begin{array}{l}2 \\
(5.00)\end{array}$ & $\begin{array}{l}15 \\
(37.50)\end{array}$ & $\begin{array}{l}23 \\
(57.5)\end{array}$ & \multirow[b]{2}{*}{$0.032 *$} & $\begin{array}{l}19 \\
(23.75)\end{array}$ & $\begin{array}{l}61 \\
(76.25)\end{array}$ & \multirow[t]{2}{*}{$0.012 *$} & \multirow{2}{*}{$\begin{array}{l}0.366 \\
(0.171-0.780\end{array}$} \\
\hline & Female (25) & $\begin{array}{l}5 \\
(20.00)\end{array}$ & $\begin{array}{l}13 \\
(52.00)\end{array}$ & $\begin{array}{l}7 \\
(28)\end{array}$ & & $\begin{array}{l}23 \\
(46.00)\end{array}$ & $\begin{array}{l}27 \\
(54)\end{array}$ & & \\
\hline \multirow[t]{2}{*}{ Group 3} & Male (39) & $\begin{array}{l}9 \\
(23.10)\end{array}$ & $\begin{array}{l}21 \\
(53.80)\end{array}$ & $\begin{array}{l}9 \\
(23.10)\end{array}$ & & $\begin{array}{l}39 \\
(50.00)\end{array}$ & $\begin{array}{l}39 \\
(50.00)\end{array}$ & \multirow[t]{2}{*}{0.517} & \multirow{2}{*}{$\begin{array}{l}1.250 \\
(0.657-2.377\end{array}$} \\
\hline & Female (36) & $\begin{array}{l}9 \\
(25.00)\end{array}$ & $\begin{array}{l}14 \\
(38.90)\end{array}$ & $\begin{array}{l}13 \\
(36.10)\end{array}$ & 0.366 & $\begin{array}{l}32 \\
(44.40)\end{array}$ & $\begin{array}{l}40 \\
(55.60)\end{array}$ & & \\
\hline
\end{tabular}

* $P$ value $<0.05$ vs. group 3 obtained through Chi-square analysis.

Table 4: Clinical characteristics of the subjects stratified according to the genotypes of I/D polymorphism of ADRA2B gene.

\begin{tabular}{|c|c|c|c|c|c|c|c|c|}
\hline Groups & BMI & SBP & DBP & BGL & HDL-C & LDL-C & TG & $\mathrm{TC}$ \\
\hline \multicolumn{9}{|l|}{ Group 1} \\
\hline II & $26.28+5.52$ & $163.67 \pm 21.79$ & $97.17 \pm 5.00$ & $5.07 \pm 0.66$ & $0.89+0.37$ & $.3 .37 \pm 0.71$ & $2.12 \pm 0.93$ & $4.68+0.59$ \\
\hline ID & $25.91+4.02$ & $159.03 \pm 16.47$ & $96.18 \pm 7.95$ & $5.31 \pm 0.59$ & $0.98 \pm 0.47$ & $3.32 \pm 0.91$ & $2.17 \pm 1.39$ & $4.80 \pm 1.00$ \\
\hline DD & $25.18 \pm 4.11$ & $160.87 \pm 22.08$ & $99.70 \pm 13.88$ & $5.19 \pm 0.47$ & $0.78 \pm 0.33$ & $3.72 \pm 1.79$ & $1.88 \pm 1.01$ & $5.01 \pm 1.79$ \\
\hline$p$ value & 0.724 & 0.841 & 0.428 & 0.487 & 0.163 & 0.486 & 0.624 & 0.789 \\
\hline \multicolumn{9}{|l|}{ Group 2} \\
\hline II & $25.47+4.40$ & $164.86+21.54$ & $96.29+2.50$ & $13.14+4.40$ & $0.65+0.25$ & $4.02+0.89$ & $1.95+0.64$ & $5.06+0.80$ \\
\hline ID & $27.01+3.39$ & $160.26 \pm 17.82$ & $93.55+5.21$ & $11.04+3.92$ & $0.78+0.35$ & $3.79 \pm 1.32$ & $2.09 \pm 1.11$ & $5.11 \pm 1.44$ \\
\hline DD & $26.58+3.76$ & $158.65 \pm 21.02$ & $93.45+3.15$ & $12.59 \pm 6.44$ & $0.83 \pm 0.22$ & $3.96 \pm 2.09$ & $1.87 \pm 0.97$ & $5.29 \pm 2.15$ \\
\hline$p$ value & 0.575 & 0.764 & 0.305 & 0.382 & 0.428 & 0.886 & 0.747 & 0.911 \\
\hline \multicolumn{9}{|l|}{ Group 3} \\
\hline II & $22.71+2.82$ & $125.11+9.26$ & $76.17 \pm 6.81$ & $4.52+0.84$ & $1.12+0.51$ & $3.38+1.15$ & $1.37 \pm 0.70$ & $5.17 \pm 1.34$ \\
\hline ID & $24.21 \pm 4.54$ & $126.68 \pm 8.25$ & $78.46 \pm 7.30$ & $4.68 \pm 0.93$ & $1.10 \pm 0.39$ & $3.42 \pm 1.37$ & $1.78 \pm 1.13$ & $5.05 \pm 1.37$ \\
\hline DD & $24.57+4.35$ & $125.59+9.62$ & $78.18+7.10$ & $4.54+0.96$ & $1.13+0.33$ & $3.31+1.00$ & $1.78+1.30$ & $5.19 \pm 1.51$ \\
\hline$p$ value & 0.329 & 0.807 & 0.524 & 0.780 & 0.969 & 0.949 & 0.383 & 0.923 \\
\hline
\end{tabular}

Data are presented as mean $\pm S D$, $p$ value $>0.05$. 


\section{Discussion}

To the best of our knowledge, there was no previous study reported on I/D polymorphism of ADRA2B gene in Malaysian essential hypertensive subjects with or without T2DM. This study probably is first of a kind to determine the association of I/D polymorphism of ADRA2B gene in essential hypertension with or without T2DM in Malaysian subjects. I/D polymorphism of ADRA2B located on human chromosome 2 [19] involves the deletion of three glutamic acids from a repeat element in the third intracellular loop of the protein [20]. D variant of the ADRA2B gene mediates the regulation of blood pressure, sympathetic tone, lipolysis and insulin secretion $[21,22]$. Several studies reported that I/D polymorphism of ADRA2B gene has been associated with an increased risk of acute coronary events [7], obesity [20] and sympathetic nervous system activity [23]. Therefore, DD genotype of ADRA2B gene confers an increased risk for EHT.

In this present study, we determined the association of I/D polymorphism of ADRA2B gene in EHT with or without T2DM. We found, DD genotypes/D allele of ADRA2B gene were associated with EHT with or without T2DM as compared with healthy individuals $(\mathrm{p}<0.05)$ in Malaysian subjects. There was statistically significant differences found between group 1 vs. group $3(\mathrm{P}=0.029)$ and group 2 vs. group $3(\mathrm{P}=0.046)$ which are in accordance with Swedish population [5], Black [6] and Finnish population [10]. The result of this study suggested that there is a possible association of deletion allele of ADRA2B gene in EHT with or without T2DM in Malaysian subjects.

This study supports the previous hypothesis that DD genotype and D allele of ADRA2B gene contribute to the development of hypertension. Vasoconstriction in humans is probably mediated by the ADRA2B [24] and the observed decreased agonist-promoted desensitization property of the deletion variant [8] may suggest that the DD genotype confers increased vasoconstriction that leads to increased peripheral resistance - a common finding in hypertension [25]. However, the findings of this study are in contrast to the results of Snapir et al. [7] and Baldwin et al. [17] $(p>0.05)$. The discrepancies with previous studies might be due to the ethnicity differences, heterogeneous population or by sampling bias.

\section{Study Limitations}

The present study has to be interpreted within the context of its limitations. First, the present study provided only the evidences of the association between I/D polymorphism of ADRA2B gene and EHT with or without T2DM at the gene level and did not address the mechanism or the functionality of the $\mathrm{D}$ variant. Second, the control subjects are not age, sex matched and they are relatively young as compared to case subjects. Although our study comprised fewer subjects, the result of this study shows DD genotypes/D allele of ADRA2B gene has a strong association with EHT with or without T2DM. However, with the findings of this study, further association studies with well-designed larger sample size subjects involving I/D polymorphism of ADRA2B gene or other candidate gene polymorphisms in related to cardiovascular diseases is recommended.

\section{Conclusion}

DD genotypes/D allele of I/D polymorphism of ADRA2B gene is possibly an important genetic marker or risk factor for EHT with or without T2DM in Malaysian subjects.

\section{Acknowledgements}

This study was supported by the Ministry of Science, Technology and Environment (MOSTE), IRPA Project Grant No. 06-02-04-10054-EAR. The authors would like to extend their gratitude to all the volunteers who involved in this study.

\section{Conflict of interests}

The authors have declared that no conflict of interest exists.

\section{References}

1. Rampal L, Rampal S, Azharc MZ, et al. Prevalence, awareness, treatment and control of hypertension in Malaysia: A national study of 16,440 subjects. Public Health 2008;122:11-8.

2. Lim TO, Morad Z. Prevalence, awareness, treatment and control of hypertension in the Malaysian adult population: results from the national health and morbidity survey 1996. Singapore Med J. 2004; 45:20-27.

3. Kohara K, Tabara Y, Nakura J, et al. Identification of hypertension-susceptibility genes and pathways by a systemic multiple candidate gene approach: the Millennium Genome Project for Hypertension. Hypertens Res. 2008; 31:203-212.

4. Agarwal A, Williams GH, Fisher ND. Genetics of human hypertension. Trends Endocrinol Metab. 2005;16:127-33.

5. Von Wowern F, Bengtsson K, Lindblad U, et al. Functional Variant in the 2B Adrenoceptor Gene, a Positional Candidate on Chromosome 2, Associates With Hypertension. Hypertension. 2004;43:592-7.

6. Lockette W, Ghosh S, Farrow S, et al. Alpha 2-adrenergic receptor gene polymorphism and hypertension in blacks. Am J Hypertens. 1995;8(4):390-4.

7. Snapir A, Heinonen P, Tuomainen TP, et al. An insertion/deletion polymorphism in the alpha2B-adrenergic receptor gene is a novel genetic risk factor for acute coronary events. J Am Coll Cardiol. 2001;37(6):1516-22.

8. Small KM, Brown KM, Forbes SL, et al. Polymorphic deletion of three intracellular acidic residues of the alpha 2B-adrenergic receptor decreases $\mathrm{G}$ protein-coupled receptor kinase mediated phosphorylation and desensitization. J Biol Chem. 2001;276:4917-2. 
9. Siitonen N, Lindström J, Eriksson J, et al. Association between a deletion/insertion polymorphism in the alpha2B-adrenergic receptor gene and insulin secretion and Type 2 diabetes. The Finnish Diabetes Prevention Study. Diabetologia. 2004;47(8):1416-24.

10. Snapir A, Scheinin M, Groop LC, et al. The insertion/deletion variation in the a2B-adrenoceptor does not seem to modify the risk for acute myocardial infarction, but may modify the risk for hypertension in sib-pairs from families with type 2 diabetes. Cardiovasc Diabetol. 2003;24:2-15.

11. Ueno LM, Frazzatto ES, Batalha LT, et al. Alpha2B-adrenergic receptor deletion polymorphism and cardiac autonomic nervous system responses to exercise in obese women. Int J Obes (Lond). 2006;30(2):214-20.

12. Papazoglou D, Papanas N, Papatheodorou K, et al. An insertion/deletion polymorphism in the alpha2B adrenoceptor gene is associated with age at onset of type 2 diabetes mellitus. Exp Clin Endocrinol Diabetes. 2006;114(8):424-7.

13. Zhang H, Li X, Huang J, et al. Cardiovascular and metabolic phenotypes in relation to the ADRA2B insertion/deletion polymorphism in a Chinese population. J Hypertens. 2005;23(12):2201-7.

14. Jousilahti P, Tuomilehto J, Vartiainen E, et al. Body weight, cardiovascular risk factors, and coronary mortality - 15-year follow-up of middle-aged men and women in eastern Finland. Circulation. 1996;93:1372-9.

15. Sivenius K, Lindi V, Niskanen L, et al. Effect of a three-amino acid deletion in the alpha2B-adrenergic receptor gene on long-term body weight change in Finnish non-diabetic and type 2 diabetic subjects. Int J Obes Relat Metab Disord. 2001;25(11):1609-14.

16. Heinonen P, Pettersson-Fernholm K, Forsblom C, et al. A deletion polymorphism of the alpha2B-adrenergic receptor gene is not associated with late complications in Type 1 diabetic patients. Diabet Med. 2005;22(2):226-8.

17. Baldwin CT, Schwartz F, Baima J, et al. Identification of a polymorphic glutamic acid stretch in the alpha2B-adrenergic receptor and lack of linkage with essential hypertension. Am J Hypertens. 1999;12(9):853-7.

18. Friedewald, WT, Levy RI, Fredrickson DS. Estimation of low density lipoprotein cholesterol without the use of the preparative ultracentrifuge. Clin Chem. 1972;18(6):499-2.

19. Lomasney JW, Lorenz W, Allen LF, et al. Expansion of the alpha 2-adrenergic receptor family: cloning and characterization of a human alpha 2-adrenergic receptor subtype, the gene for which is located on chromosome 2. Proc Natl Acad Sci USA. 1990;87(13):5094-8.

20. Heinonen $\mathrm{P}$, Koulu M, Pesonen $\mathrm{U}$, et al. Identification of a three-amino acid deletion in the alpha2B-adrenergic receptor that is associated with reduced basal metabolic rate in obese subjects. J Clin Endocrinol Metab. 1999;84(7):2429-33.

21. Ruffolo RR Jr, Nichols AJ, Stadel JM, et al. Pharmacologic and therapeutic applications of alpha 2-adrenoceptor subtypes. Annu Rev Pharmacol Toxicol. 1993;33:243-9

22. Philipp M, Brede M, Hein L. Physiological significance of alpha (2)-adrenergic receptor subtype diversity: one receptor is not enough. Am J Physiol Regul Integr Comp Physiol. 2003;283:287-95.

23. Suzuki N, Matsunaga T, Nagasumi K, et al. Alpha(2B)-adrenergic receptor deletion polymorphism associates with autonomic nervous system activity in young healthy Japanese. J Clin Endocrinol Metab. 2003;88:1184-7.

24. Kable JW, Murrin LC, Bylund DB. In vivo gene modification elucidates subtype-specific functions of alpha 2-adrenergic receptors. J Pharmacol Exp Ther. 2000;293:1-7.

25. Beevers G, Lip GY, O'Brien E. ABC of hypertension: The pathophysiology of hypertension. BMJ. 2001; 322(7291):912-6. 